\title{
Effects of the traditional medicine, Dai-Ken-Chu-To on obesity and glucose intolerance induced by long-term feeding on a high-fat diet in mice
}

\author{
Maho Sumiyoshi and Yoshiyuki Kimura* \\ Division of Biochemical Pharmacology, Department of Basic Medical Research, Ehime University Graduate School of Medicine, Shitsukawa, Toon City, Ehime \\ 791-0295, Japan
}

\begin{abstract}
The traditional medicine Dai-Ken-Chu-To (DK) is used to treat gastrointestinal diseases. The drug may have an anti-obesity effect through its gastrointestinal activities. In this study, we examined the effects of DK on obesity and glucose intolerance induced by long-term feeding on a HF diet. Male C57BL/6N mice (5 weeks old) consumed a HF diet, a HF diet plus $1 \%$ or $3 \%$ DK extract, or a HF diet plus 0.5 or $1 \%$ zanthoxylum fruit extract for 20 weeks. The DK extract (500 or $1000 \mathrm{mg} / \mathrm{kg}$ ) and the lipase inhibitor orlistat $(50 \mathrm{mg} / \mathrm{kg}$ ) reduced elevated levels of triacylglycerol (TG) in plasma in the oral lipid tolerance test. The HF diet plus $3 \%$ DK extract inhibited the increase in body weight at weeks 8, 9, 11 and 12, compared with the HF diet alone. The DK extract (1\% and 3\%), and the zanthoxylum fruit extract (1\%) lowered the elevated plasma glucose levels in mice fed the HF diet. DK extract or zanthoxylum fruit extract might be useful for preventing obesity and/or glucose intolerance induced by a HF diet.
\end{abstract}

\section{Introduction}

The traditional medicine Dai-Ken-Chu-To (Da-Jiang-ZhongTang in Chinese), a mix of four natural components, is used to treat abdominal discomfort including pain and distention in Japan. DaiKen-Chu-To has been found to improve gastrointestinal motility, postoperative adhesion, and paralytic ileus after abdominal surgery in basic medicinal and clinical studies [1-8]. Furthermore, it reportedly increases gastrointestinal motility by raising levels of calcitonin generelated peptide as well as acetylcholine and motilin [9-12]. Thus, DaiKen-Chu-To (DK) has a strong gastrointestinal activity. Obesity is one of the fastest-growing diseases in many areas of the world including Europe, the United States, and Japan. Obesity results from an imbalance between energy intake and expenditure, and is closely associated with life-style-related diseases such as hyperlipidemia, hypertension, atherosclerosis and non-insulin-dependent diabetes mellitus and with increased risk of coronary heart disease [13]. It has been reported that variations in total energy intake and diet composition are important in the regulation of metabolic processes $[14,15]$. Furthermore, it has been suggested that dietary fat promotes body fat storage more effectively than dietary carbohydrate. Therefore, inhibition of the digestion and absorption of dietary fat is a key to treating obesity. Dietary fat is not directly absorbed from the small intestine unless it has been subjected to the actions of pancreatic lipase [16]. In this study, we examined the effects of a modified DK extract (without maltose powder) on obesity and glucose intolerance induced in mice by long-term feeding of a high-fat diet.

\section{Materials and methods}

\section{Materials}

A modified Dai-Ken-Chu-To extract without maltose powder
(DK) (Lot. 070723AG), and a zanthoxylum fruit extract (Zanthoxylum piperitum De Candolle, Rutaceae) (Lot. 081021AG) were obtained from by Nihon Funmatsu Pharmacy Co. Ltd. (Osaka, Japan). DK $(10 \mathrm{~g})$ is a mixture of powdered extract from dried ginger rhizome (Zingiber officinale Roscoe Zingiberaceae) (5 g), ginseng root (Panax ginseng C.A. Meyer, Araliaceae) (3 g) and zanthoxylum fruit (2 g). The Triglyceride E-Test, Total Cholesterol E-Test, Nonesterified Fatty Acid (NEFA) C-Test and Glucose CII-Test kits were purchased from Wako Pure Chemical Co. Ltd. (Osaka, Japan). Cornstarch, casein, cellulose, soybean oil, lard, mineral mixture (AIN-76), and vitamin mixture (AIN-76) were from Clea Japan Co. (Osaka, Japan). The standard diet AIN-93M (protein $13.9 \%$ calorie, fat $9.7 \%$ calorie and carbohydrate $77.0 \%$ calorie) (total $377 \mathrm{kcal} / 100 \mathrm{~g}$ diet) was purchased from Test Diet Co. (IN, USA). The lipase inhibitor orlistat was obtained from Roche Pharmaceuticals Ltd. (Basel, Switzerland). Other chemicals were of reagent grade.

\section{Composition of diet}

The basic composition of the experimental high-fat diet was as follows ( $\mathrm{g} / 100 \mathrm{~g}$ food): cornstarch 30 , casein 14 , sugar 10 , cellulose 5 , soybean oil 4 , lard 32.5, mineral mixture 1 , and vitamin mixture 1 (total $546 \mathrm{kcal} / 100 \mathrm{~g} \mathrm{diet})$. The composition of the other experimental diets is

Correspondence to: Yoshiyuki Kimura, Division of Biochemical Pharmacology, Department of Basic Medical Research, Ehime University Graduate School of Medicine, Shitsukawa, Toon City, Ehime 791-0295, Japan, Tel: (+81)-89-9605922, E-mail: yokim@m.ehime-u.ac.jp

Key words: Dai-Ken-Chu-To, anti-obesity, high-fat diet, glucose intolerance

Received: September 06, 2015; Accepted: September 25, 2015; Published: September 28, 2015 
shown in Table 1 . To avoid the auto-oxidation of fat content, the feeds were stored at $-30^{\circ} \mathrm{C}$ and freshly prepared each day.

\section{Animals}

Male ICR mice ( 5 weeks old) and male C57BL/6N mice (4 weeks old) obtained from Japan SLC (Shizuoka, Japan) were housed in a room with a 12-h light/dark cycle and controlled temperature and humidity. The animals had free access to food and water, and were used after 1 week of adaptation to the lighting conditions. Mice were treated according to the ethical guidelines of the Animal Center, Ehime University Graduate School of Medicine. The Animal Studies Committee of Ehime University approved the experimental protocol.

\section{Plasma triacylglycerol (TG) concentration after oral administration of corn oil emulsion to ICR mice}

DK extract (500 or $1000 \mathrm{mg}$ ), zanthoxylum fruit extract (500 or $1000 \mathrm{mg}$ ) and the lipase inhibitor orlistat $(50 \mathrm{mg}$ ) were suspended in distilled water $(10 \mathrm{~mL})$. A mixture of corn oil $(5 \mathrm{~g})$ was emulsified with $5 \%$ bovine serum albumin (BSA) $(10 \mathrm{~mL})$. After the mice were deprived of food for $5 \mathrm{~h}$, the DK (500 or $1000 \mathrm{mg} / \mathrm{kg}$ body weight), zanthoxylum fruit extract ( 500 or $1000 \mathrm{mg} / \mathrm{kg}$ body weight), or orlistat (50 mg/kg body weight) was administered orally $20 \mathrm{~s}$ before the oral administration of the corn oil emulsion $(5 \mathrm{~g} / \mathrm{kg})$. Blood samples were taken from the tail at $0,0.5,1,2$ and $4 \mathrm{~h}$ after administration of the corn oil emulsion using a heparinized capillary tube, and centrifuged at 5500 $\mathrm{g}$ for $5 \mathrm{~min}$ in a KUBOTA 3220 centrifuge (Kubota, Tokyo, Japan) to obtain the plasma. The plasma TG concentration was determined using the Triglyceride E-Test kit.

\section{Body weight, liver and white adipose tissue weights,} plasma lipids, and liver TG and TC concentrations

Male C57BL/6N mice (4 weeks old) were divided into six groups that were matched for body weight, after 1 week of being fed laboratory pellet chow ad libitum. The control group was given the standard purified diet AIN-93M ad libitum during the experimental period. The mice consumed the high-fat (HF) diet, the HF diet containing 1 or $3 \%$ DK extract, or the HF diet containing 0.5 or $1 \%$ zanthoxylum fruit extract for 20 weeks. The body weight of each mouse was measured once a week and the total amount of food consumed was recorded weekly. After the mice had been fed these diets for 20 weeks, blood was taken from each mouse by venous puncture under anesthesia with diethylether; the mice were killed with an overdose of diethylether. Experiments were performed in a ventilated room. The plasma was prepared by centrifugation and frozen at $-80^{\circ} \mathrm{C}$ for analysis. The plasma TG, TC and NEFA concentrations were determined using the Triglyceride E-Test, Total Cholesterol E-Test and NEFA-Test kits. The liver and white adipose tissue were dissected and weighed. To measure the liver TG and TC concentrations, liver $(1 \mathrm{~g})$ was homogenized with distilled water $(10 \mathrm{~mL})$. The liver TG and TC concentrations were measured by the methods of Fletcher [17] and Zak et al. [18], respectively.

\section{Oral glucose tolerance test (OGTT)}

The OGTT was performed at week 19 on mice fed the standard diet, the HF diet, the HF diet plus DK extract, and the HF diet plus zanthoxylum fruit extract. Briefly, after at least $5 \mathrm{~h}$ of food deprivation, glucose (100 mg/mouse) was administered orally to the mice. Blood samples were taken from the tail at specific times and blood glucose concentrations were measuring using GLUCOCARD ${ }^{\mathrm{TM}}$ (GT-1640, Arkray, Kyoto, Japan).

\section{Statistical analysis}

All values are expressed as the mean \pm S.E.M. Data were subjected to a one-way analysis of variance (ANOVA), and differences among means were analyzed using Fisher's protected LSD test. Differences were considered significant at $P<0.05$.

\section{Results}

\section{Plasma TG levels in the oral lipid tolerance test}

Figure 1 shows the time course of the change in the plasma TG level after the oral administration of the lipid emulsion. A maximum level of TG was reached at $2 \mathrm{~h}$. DK ( 500 or $1000 \mathrm{mg} / \mathrm{kg}$ ) or the lipase inhibitor orlistat $(50 \mathrm{mg} / \mathrm{kg}$ ) reduced the elevated plasma TG level 2 and $4 \mathrm{~h}$ after the administration of the lipid emulsion. The zanthoxylum fruit extract had no effect on the plasma TG level in the oral lipid tolerance test (data not shown).

\section{Energy intake, body weight and tissue weight, and plasma} and hepatic lipids in mice fed a HF-diet

Mean food consumption per day per mouse for 20 weeks did not differ among mice fed the standard diet (AIN-93M), the HF-diet, the HF diet plus DK extract (1 or 5\%), and the HF diet plus zanthoxylum fruit extract ( 0.5 or $1 \%$ ), being $10.2 \pm 0.11 \mathrm{kcal}$ (AIN-93M diet), 12.7 $\pm 0.16 \mathrm{kcal}$ (HF diet), $12.2 \pm 0.16 \mathrm{kcal}$ (HF plus $1 \%$ DK extract), $11.3 \pm 0.11 \mathrm{kcal}$ (HF plus $3 \%$ DK extract), $12.7 \pm 0.70 \mathrm{kcal}$ (HF plus $0.5 \%$ zanthoxylum fruit extract) and $12.3 \pm 0.15 \mathrm{kcal}$ (HF plus $1 \%$ zanthoxylum fruit extract), respectively. Figure 2 shows the changes in body weight of the groups during the experiment. Mice fed the HF diet

Table 1. Composition of experimental diets.

\begin{tabular}{|c|c|c|c|c|c|}
\hline$(\mathrm{g} / \mathbf{1 0 0 g})$ & HF & HF plus $1 \%$ DK extract & HF plus 3\% DK extract & $\begin{array}{c}\text { HF plus } 0.5 \% \text { zanthoxylum } \\
\text { fruit extract }\end{array}$ & $\begin{array}{l}\text { HF plus } 1 \% \text { zanthoxylum } \\
\text { fruit extract }\end{array}$ \\
\hline Corn starch & 30.0 & 29.0 & 27.0 & 29.5 & 29.0 \\
\hline Casein & 14.0 & 14.0 & 14.0 & 14.0 & 14.0 \\
\hline Sucrose & 10.0 & 10.0 & 10.0 & 10.0 & 10.0 \\
\hline Cellulose & 5.0 & 5.0 & 5.0 & 5.0 & 5.0 \\
\hline Soybean oil & 4.0 & 4.0 & 4.0 & 4.0 & 4.0 \\
\hline Lard & 32.5 & 32.5 & 32.5 & 32.5 & 32.5 \\
\hline Minearl mixture & 3.5 & 3.5 & 3.5 & 3.5 & 3.5 \\
\hline Vitamin mixture & 1.0 & 1.0 & 1.0 & 1.0 & 1.0 \\
\hline $\begin{array}{l}\text { DK or zanthoxylum fruit } \\
\text { extract }\end{array}$ & 0 & 1.0 & 3.0 & 0.5 & 1.0 \\
\hline Energy kcal/100 g & 546 & 546 & 546 & 546 & 546 \\
\hline
\end{tabular}




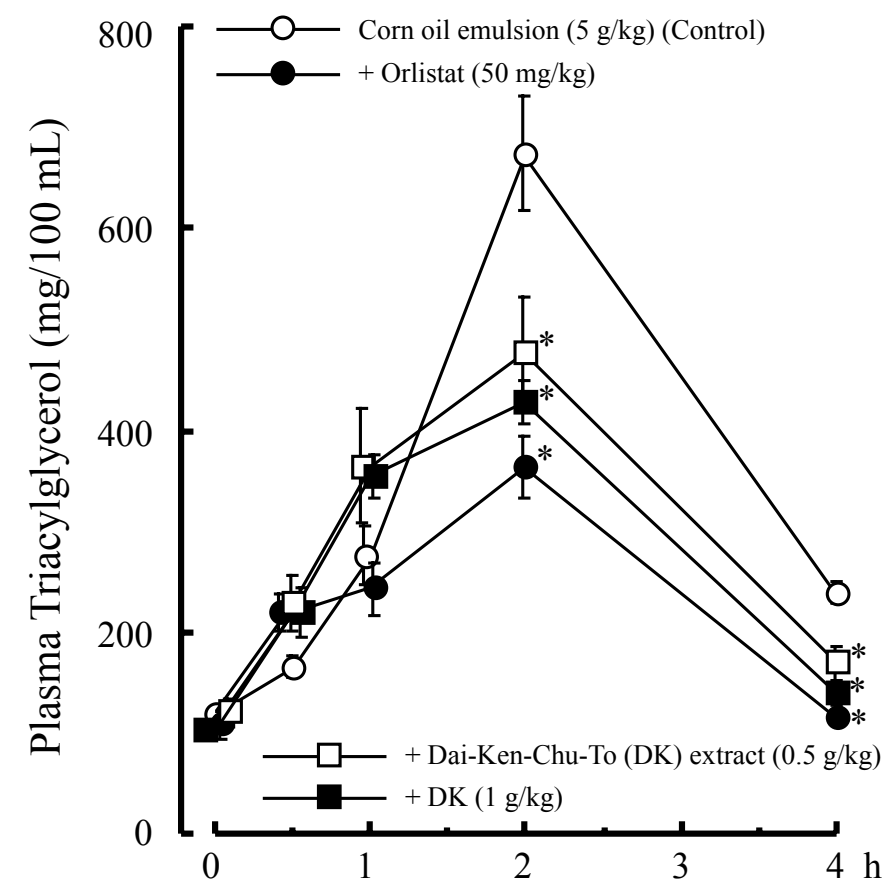

Figure 1 Effect of DK extract, zanthoxylum fruit extract and orlistat on plasma TG concentrations after the oral lipid tolerance test in mice.

Values are means \pm S.E.M., $\mathrm{n}=8$. $* P<0.05$, significantly different compared with mice administered the lipid emulsion alone (control).

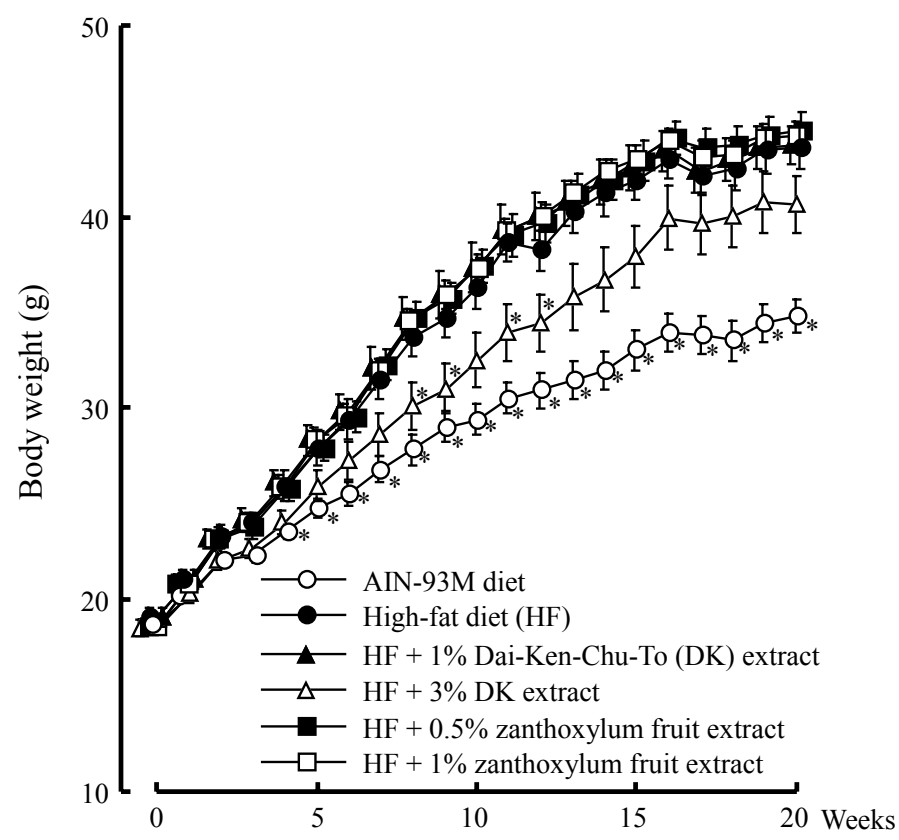

Figure 2 Effects of DK extract and zanthoxylum fruit extract on body weight in mice fed a HF diet for 20 weeks

Values are means \pm S.E.M., $\mathrm{n}=8 . * P<0.05$, significantly different compared with mice fed the HF diet.

showed significant increases in body weight at 4-20 weeks compared with those fed the standard diet. The intake of the $1 \%$ DK extract, and 0.5 or $1 \%$ zanthoxylum fruit extract, had no effect on the increase in body weight induced by the HF diet during the 20 weeks. The $3 \%$ DK extract significantly inhibited the increase in body weight at weeks 8 ,
911 and 12, and overall, tended to inhibit the increase in body weight caused by the HF diet (Figure 2).

The weights of the liver and mesenteric and epididymal adipose tissue were increased together with body weight in mice fed the HF diet compared with those on the standard diet (Table 2). The DK extract and zanthoxylum fruit extract had no effect on the increases caused by the HF diet during the 20 weeks (Table 2). The plasma TC levels were increased in mice on the HF diet compared with those on the standard diet. Neither the DK extract nor zanthoxylum fruit extract had any effect on the increased TC levels in mice fed the HF diet (Table 3). Plasma TG and NFFA concentrations did not differ significantly between the mice on the standard diet, HF diet, HF diet plus DK extract, and HF diet plus zanthoxylum fruit extract (Table 3). Liver TG and TC levels did not differ significantly among mice fed the HF diet, HF diet plus DK extract, and HF diet plus zanthoxylum fruit extract (data not shown).

\section{Plasma glucose levels in the OGTT}

Figure 3 shows the time course of the change in the plasma glucose level after the oral administration of glucose (100 mg/mouse). A maximum level was reached at $15 \mathrm{~min}$. The HF diet plus 1 or $3 \%$ DK extract significantly reduced the elevated plasma glucose level 15 and $30 \mathrm{~min}$ after the administration of glucose compared with the HF diet alone. The HF diet plus $1 \%$ zanthoxylum fruit extract reduced the elevated plasma glucose level 15 and 60 min after the administration of glucose, and the HF diet plus $0.5 \%$ zanthoxylum fruit extract reduced the elevated plasma glucose level at $15 \mathrm{~min}$ in the OGTT (Figure 3).

Table 2. Effects of DK extract or zanthoxylum fruit extract on the weight of liver, mesenteric and epididymal white adipose tissues in mice fed a HF diet for 20 weeks.

\begin{tabular}{|l|c|c|c|}
\hline Treatment & Liver (g) & $\begin{array}{c}\text { Mesenteric } \\
\text { adipose tissue (g) }\end{array}$ & $\begin{array}{c}\text { Epididymal } \\
\text { adipose tissue (g) }\end{array}$ \\
\hline AIN-93 M diet & $1.44 \pm 0.08^{*}$ & $0.56 \pm 0.04^{*}$ & $1.49 \pm 0.09^{*}$ \\
\hline HF diet & $2.00 \pm 0.12$ & $1.33 \pm 0.10$ & $2.23 \pm 0.14$ \\
\hline HF plus 1\% DK extract & $2.23 \pm 0.19$ & $1.32 \pm 0.14$ & $1.81 \pm 0.21$ \\
\hline HF plus 3\% DK extract & $1.66 \pm 0.13$ & $1.02 \pm 0.14$ & $1.87 \pm 0.15$ \\
\hline $\begin{array}{l}\text { HF plus 0.5\% zanthoxylum } \\
\text { fruit extract }\end{array}$ & $2.02 \pm 0.09$ & $1.33 \pm 0.08$ & $1.91 \pm 0.11$ \\
\hline $\begin{array}{l}\text { HF plus 1\% zanthoxylum } \\
\text { fruit extract }\end{array}$ & $1.98 \pm 0.07$ & $1.33 \pm 0.10$ & $1.74 \pm 0.13$ \\
\hline
\end{tabular}

Results are means \pm S.E.M., $\mathrm{n}=8,{ }^{*} P<0.05$, significantly different compared with mice fed HF diet.

Table 3. Effects of DK extract or zanthoxylum fruit extract on plasma TG, TC and NEFA levels in mice fed a HF diet for 20 weeks.

\begin{tabular}{|l|c|c|c|}
\hline Treatment & $\begin{array}{c}\text { TG } \\
(\mathbf{m g} / \mathbf{1 0 0} \mathbf{~ m L}\end{array}$ & $\begin{array}{c}\text { TC } \\
(\mathbf{m g} / \mathbf{1 0 0} \mathbf{~ m L})\end{array}$ & $\begin{array}{c}\text { NEFA } \\
(\boldsymbol{\mu M})\end{array}$ \\
\hline AIN-93 M diet & $53.6 \pm 3.2$ & $164.9 \pm 7.0 *$ & $0.65 \pm 0.04$ \\
\hline HF diet & $51.7 \pm 2.8$ & $200.4 \pm 9.4$ & $0.56 \pm 0.04$ \\
\hline HF plus 1\% DK extract & $42.4 \pm 2.3$ & $237.0 \pm 11.9$ & $0.59 \pm 0.03$ \\
\hline HF plus 3\% DK extract & $47.1 \pm 3.1$ & $200.6 \pm 11.0$ & $0.57 \pm 0.05$ \\
\hline $\begin{array}{l}\text { HF plus 0.5\% zanthoxylum } \\
\text { fruit extract }\end{array}$ & $53.3 \pm 2.6$ & $240.1 \pm 4.9$ & $0.57 \pm 0.02$ \\
\hline $\begin{array}{l}\text { HF plus 1\% zanthoxylum } \\
\text { fruit extract }\end{array}$ & $49.0 \pm 5.1$ & $217.9 \pm 9.8$ & $0.52 \pm 0.03$ \\
\hline
\end{tabular}

Results are means \pm S.E.M., $\mathrm{n}=8, * P<0.05$, significantly different compared with mice fed HF diet. 


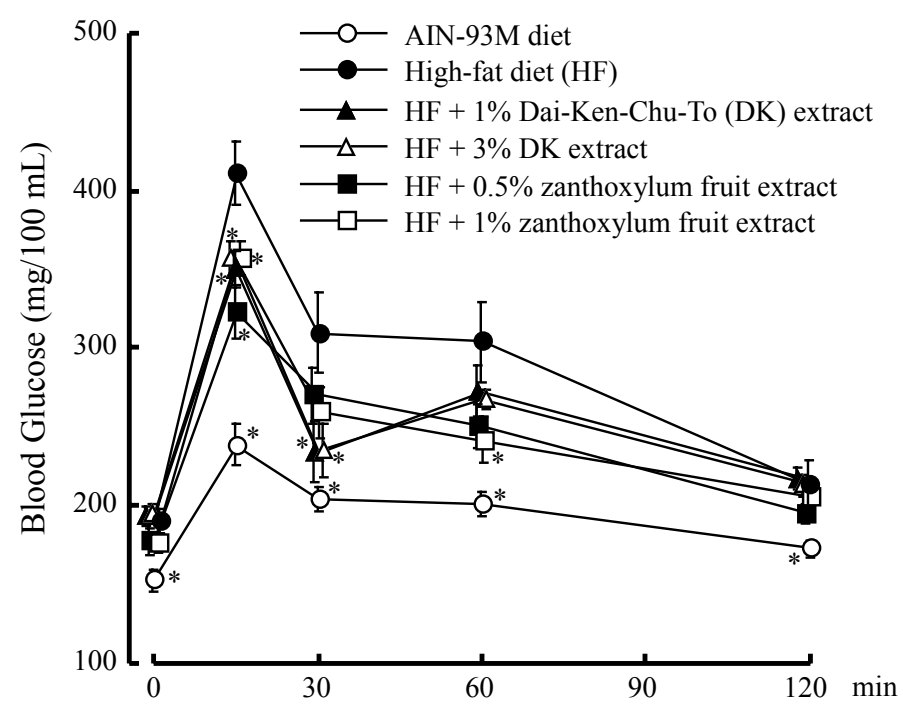

Figure 3 Effects of DK extract and zanthoxylum fruit extract on the plasma glucose concentration in OGTT with mice fed a HF diet for 20 weeks.

Values are means \pm S.E.M., $\mathrm{n}=8 . * P<0.05$, significantly different compared with mice fed the HF diet.

\section{Discussion}

There are a number of studies describing HF diet-induced obesity [17-20] Obesity is closely associated with many metabolic disorders including insulin-resistant diabetic mellitus, hyperlipidemia, hypertension, and atherosclerosis. These factors can increase the risk of coronary heart disease $[21,22]$. Recently, we reported that chronic intake of a HF or high-sucrose diet resulted in different types of glucose intolerance with or without obesity [23]. In a series of studies on the effects of natural products on HF diet-induced obesity, we found that the intake of oolong tea [24], tea saponins [25], chitin-chitosan [26,27], chondrotin sulfate [28], Platycodi saponins [29,30], chikusetsaponins isolated from Panax japnicum [31], and polyphenols of Salix matudana leaves [32] had an effect. DK has been found to improve gastrointestinal motility, postoperative adhesion, and paralytic ileus after abdominal surgery in basic medicinal and clinical studies in Japan [1-8]; therefore, this drug may have an anti-obesity effect through gastrointestinal activities. DK consists of dried ginger rhizome (Zingiber officinale Roscoe Zingiberaceae), ginseng root (Panax ginseng C.A. Meyer, Araliaceae) and zanthoxylum fruit (Zanthoxylum piperitum De Candolle, Rutaceae). We have reported that ginger rhizomes and ginseng saponins had anti-obesity actions through the inhibition of pancreatic lipase $[33,34]$. In this study, we examined the effects of DK extract and Zanthoxylum piperitum fruit extract on obesity and glucose intolerance induced in mice by feeding the high-fat diet long-term. The DK extract and the lipase inhibitor orlistat inhibited the increase in the plasma TG level in the lipid tolerance test, but the zanthoxylum fruit extract had no effect. The DK inhibited the obesity caused by the HF diet. These findings suggest the anti-obesity effect of the DK extract to be partly due to the prevention of fat storage by the inhibition of lipid absorption from the small intestine through the inhibitory effect of the ginger extract [33] and ginseng saponins [34] of Ginseng roots in DK on pancreatic lipase. It is well-known that obesity is closely associated with insulin-resistant diabetes mellitus [22], and we also found that the obesity induced by chronic feeding of a HF diet caused insulin-resistance with glucose intolerance and a reduction in insulin sensitivity [23]. In this study, the feeding of the DK and zanthoxylum fruit extracts improved the glucose intolerance induced by a HF diet for 20 weeks. This finding suggests that the DK and zanthoxylum extracts stimulate insulin sensitivity including peroxisom proliferator-activated receptor (PPAR) $\gamma$, and adipocytokines (leptin and adiponectin etc). The mechanism(s) by which the DK or zanthoxylum fruit extract improved the insulin-resistance and obesity induced by a HF diet are unknown. Experiments are now in progress to isolate the insulinsensitive stimulatory compounds from DK or zanthoxylum fruit extract.

\section{Conclusions}

DK or zanthoxylum fruit extract might be useful for preventing obesity and/or glucose intolerance caused by a HF-diet.

\section{Funding}

This work was supported by Research Grants from Nihon Funmatsu Pharmacy Co. (Osaka, Japan).

\section{Acknowledgments}

A modified Dai-Ken-Chu-To extract without maltose powder (DK) (Lot. 070723AG), and a zanthoxylum fruit extract (Zanthoxylum piperitum De Candolle, Rutaceae) (Lot. 081021AG). We wish to thank Nihon Funmatsu Pharmacy Co. for these materials. Dr. Y. Kimura designed the experiments, conducted all the experimental work, wrote the manuscript, and discussed it with Dr. M. Sumiyoshi; Dr. M. Sumiyoshi performed all the experimental analyses and helped in writing the manuscript. This manuscript is dedicated to Dr. Maho Sumiyoshi, 42 years old, who passed away on December $11^{\text {th }} 2014$. I wish to express my posthumous gratitude to Dr. Maho Sumiyoshi, first author of this work, for her commitment to carrying out the experiments, discussing the results, writing the manuscript, and her overall contribution to this work.

\section{References}

1. Itoh T, Yamakawa J, Mai M, Yamaguchi N, Kanda T (2002) The effect of the herbal medicine dai-kenchu-to on post-operative ileus. J Int Med Res 30: 428-432. [Crossref]

2. Suehiro T, Matsumata T, Shikada Y, Sugimachi K (2005) The effect of the herbal medicines dai-kenchu-to and keishi-bukuryo-gan on bowel movement after colorectal surgery. Hepatogastroenterology 52: 97-100. [Crossref]

3. Endo S, Nishida T, Nishikawa K, Nakajima K, Hasegawa J, et al. (2006) Dai-kenchuto, a Chinese herbal medicine, improves stasis of patients with total gastrectomy and jejunal pouch interposition. Am J Surg 192: 9-13. [Crossref]

4. Iwai N, Kume Y, Kimura O, Ono S, Aoi S, et al. (2007) Effects of herbal medicine DaiKenchu-to on anorectal function in children with severe constipation. Eur J Pediatr Surg 17: 115-118. [Crossref]

5. Tokita Y, Satoh K, Sakaguchi M, Endoh Y, Mori I, et al. (2007) The preventive effect of Daikenchuto on postoperative adhesion-induced intestinal obstruction in rats. Inflammopharmacology 15: 65-66. [Crossref]

6. Suzuki H, Inadomi JM, Hibi T (2009) Japanese herbal medicine in functional gastrointestinal disorders. Neurogastroenterol Motil 21: 688-696. [Crossref]

7. Kawasaki N, Nakada K, Suzuki Y, Furukawa Y, Hanyu N, et al. (2009) Effect of Daikenchu-to on gastrointestinal motility and gastric emptying. Int $J$ Surg 7: 218-222. [Crossref]

8. Kawahara H, Yanaga K (2009) The herbal medicine Dai-Kenchu-To directly stimulates colonic motility. Surg Today 39: 175-177. [Crossref]

9. Shibata C, Sasaki I, Naito H, Ueno T, Matsuno S (1999) The herbal medicine DaiKenchu-Tou stimulates upper gut motility through cholinergic and 5-hydroxytryptamine 3 receptors in conscious dogs. Surgery 126: 918-924. [Crossref]

10. Nagano T, Itoh H, Takeyama M (2000) Effects of Dai-kenchu-to on levels of 5-hydroxytryptamine (serotonin) and vasoactive intestinal peptides in human plasma. Biol Pharm Bull 23: 352-353. [Crossref] 
11. Sato Y, Katagiri F, Inoue S, Itoh H, Takeyama M (2004) Dai-kenchu-to raises levels of calcitonin gene-related peptide and substance P in human plasma. Biol Pharm Bull 27: 1875-1877. [Crossref]

12. Kono T, Koseki T, Chiba S, Ebisawa Y, Chisato N, Iwamoto J, Kasai S (2008) Colonic vascular conductance increased by Daikenchuto via calcitonin gene-related peptide and receptor-activity modifying protein 1 . J Surg Res 150: 78-84. [Crossref]

13. Leonhardt M, Hrupka B, Langhans W (1999) New approaches in the pharmacological treatment of obesity. Eur J Nutr 38: 1-13. [Crossref]

14. Hill JO, Melanson EL, Wyatt HT (2000) Dietary fat intake and regulation of energy balance: implications for obesity. J Nutr 130: 284S-288S. [Crossref]

15. Leslie WS, Lean ME, Baillie HM, Hankey CR (2002) Weight management: a comparison of existing dietary approaches in a work-site setting. Int $J$ Obes Relat Metab Disord 26: 1469-1475. [Crossref]

16. Verger R (1984) Pancreatic lipase. (Eds: By Borgstrom B and Brockman HL) pp. 83105, Elsevier, Amsterdam.

17. Flatt JP (1987) The difference in the storage capacities for carbohydrate and for fat and its implications in the regulation of body weight. Ann N Y Acad Sci 499: 104-123. [Crossref]

18. Awad AB, Bernardis LL, Fink CS (1990) Failure to demonstrate an effect of dietary fatty acid composition on body weight, body composition and parameters of lipid metabolism in mature rats. $J$ Nutr 120: 1277-1282. [Crossref]

19. Shimomura Y, Tamura T, Suzuki M (1990) Less body fat accumulation in rats fed a safflower oil diet than in rats fed a beef tallow diet. J Nutr 120: 1291-1296. [Crossref]

20. Hill JO, Peters JC, Lin D, Yakubu F, Greene H, et al. (1993) Lipid accumulation and body fat distribution is influenced by type of dietary fat fed to rats. Int $J$ Obes Relat Metab Disord 17: 223-236. [Crossref]

21. Plutzky J (2000) Emerging concepts in metabolic abnormalities associated with coronary artery disease. Curr Opin Cardiol 15: 416-421. [Crossref]

22. Reaven GM (1988) Banting lecture 1988. Role of insulin resistance in human disease Diabetes 37: 1595-1607. [Crossref]

23. Sumiyoshi M, Sakanaka M, Kimura Y (2006) Chronic intake of high-fat and high- sucrose diets differentially affects glucose intolerance in mice. J Nutr 136: 582-587. [Crossref]

24. Han LK, Takaku T, Li J, Kimura Y, Okuda H (1999) Anti-obesity action of oolong tea. Int J Obes Relat Metab Disord 23: 98-105. [Crossref]

25. Han LK, Kimura Y, Kawashima M, Takaku T, Taniyama T, et al. (2001) Anti-obesity effects in rodents of dietary teasaponin, a lipase inhibitor. Int $J$ Obes Relat Metab Disord 25: 1459-1464. [Crossref]

26. Han LK, Kimura Y, Okuda H (1999) Reduction in fat storage during chitin-chitosan treatment in mice fed a high-fat diet. Int J Obes Relat Metab Disord 23: 174-179. [Crossref]

27. Sumiyoshi M, Kimura Y (2006) Low molecular weight chitosan inhibits obesity induced by feeding a high-fat diet long-term in mice. J Pharm Pharmacol 58: 201-207. [Crossref]

28. Han LK, Sumiyoshi M, Takeda T, Chihara H, Nishikiori T, et al. (2000) Inhibitory effects of chondroitin sulfate prepared from salmon nasal cartilage on fat storage in mice fed a high-fat diet. Int J Obes Relat Metab Disord 24: 1131-1138. [Crossref]

29. Han LK, Xu BJ, Kimura Y, Zheng Yn, Okuda H (2000) Platycodi radix affects lipid metabolism in mice with high fat diet-induced obesity. J Nutr 130: 2760-2764 [Crossref]

30. Han LK, Zheng YN, Xu BJ, Okuda H, Kimura Y (2002) Saponins from platycodi radix ameliorate high fat diet-induced obesity in mice. J Nutr 132: 2241-2245. [Crossref]

31. Han LK, Zheng YN, Yoshikawa M, Okuda H, Kimura Y (2005) Anti-obesity effects of chikusetsusaponins isolated from Panax japonicus rhizomes. BMC Complement Altern Med 5: 9. [Crossref]

32. Han LK, Sumiyoshi M, Zhang J, Liu MX, Zhang XF, et al. (2003) Anti-obesity action of Salix matsudana leaves (Part 1). Anti-obesity action by polyphenols of Salix matsudana in high fat-diet treated rodent animals. Phytother Res 17: 1188-1194. [Crossref]

33. Han LK, Gong XJ, Kawano S, Saito M, Kimura Y, et al. (2005) Antiobesity actions of Zingiber officinale Roscoe. Yakugaku Zasshi 125: 213-217. [Crossref]

34. Liu W, Zheng Y, Han L, Wang H, Saito M, et al. (2008) Saponins (Ginsenosides) from stems and leaves of Panax quinquefolium prevented high-fat diet-induced obesity in mice. Phytomedicine 15: 1140-1145. [Crossref]

Copyright: (C2015 Sumiyoshi M. This is an open-access article distributed under the terms of the Creative Commons Attribution License, which permits unrestricted use, distribution, and reproduction in any medium, provided the original author and source are credited. 